VOLUMINA JURASSICA, 2020, XVIII (1): 37-46

DOI: $10.7306 /$ NJ.18.3

\title{
Arietites solarium (Quenstedt, 1883) - a diagnostic ammonite species in the Lower Jurassic (Early Sinemurian, Bucklandi Zone) of SW Germany
}

\author{
Armin SCHERZINGER ${ }^{1}$, Stefan GRÄBENSTEIN ${ }^{2}$, Günter SCHWEIGERT ${ }^{3}$
}

Key words: ammonites, Arietitidae, Early Sinemurian, biostratigraphy, correlation, Germany.

\begin{abstract}
The coarse-ribbed and big-sized Arietites solarium (Quenstedt, 1883) is one of the largest-grown and most iconic ammonite taxa in the entire Swabian Lower Jurassic; however, despite previous revisions including the designation of a lectotype, there has been some confusion concerning its correct identification, and its type horizon within the Lower Sinemurian Arietenkalk Formation was not exactly known. Arietites solarium characterises the herein introduced solarium Biohorizon of the upper Bucklandi Zone of the Sinemurian. For nomenclatorial stability, we designate a neotype based on the only surviving specimen of Quenstedt's original type series. In addition, we provide a preliminary succession of recognized biohorizons in the Lower Sinemurian of Swabia, which will make correlations with other areas more reliable.
\end{abstract}

\section{INTRODUCTION}

The fossils from the Lower Jurassic deposits of southern Germany have been studied since the earliest beginnings of scientific palaeontology (e.g., Reinecke, 1818; Stahl, 1824; Zieten, 1830-1833; Buch, 1839). The bulk of ammonite taxa occurring in this area were described in the monographs of Quenstedt (1845-1849, 1856-1857, 1883-1885), Oppel (1856, 1862 ) and Reynès (1879), followed by a few early revisions and studies (Hyatt, 1889; Pompeckj, 1893-1896, 1901; Dietz, 1922; Schmidt, 1925; Jaworski, 1931). This long tradition suggests that the biostratigraphic data of the described taxa are available and that there should exist a well-known biostratigraphic resolution of the lithostratigraphic succession. The Sinemurian Arietenkalk Formation - named after the abundance of big-sized ammonites of the family Arietitidae - is partly very rich in ammonites and other invertebrates.
However, the collecting of these impressive fossils has never focused on their exact stratigraphical horizons but mostly on aesthetic criteria. Major attempts at providing detailed biostratigraphic schemes for the Lower Sinemurian deposits were undertaken first by Fiege $(1926,1929)$ and later by Walliser (1956a). At that time, numerous small quarries were still active, where the limestone beds were exploited for local building stones or road metal. Subsequently, all of these quarries were abandoned and filled in, and today the Arietenkalk Formation is exposed only temporarily and in a few natural outcrops along streams (Fig. 1). Only very few further data have been published, mostly focussing on rare or newly recorded taxa (e.g., Hölder, 1936; Hoffmann, 1964; Schlatter, 1976, 1983, 1984, 1988; Gebhard, Schlatter, 1977; Bloos, 1979, 1988, 2014; Schweigert et al., 2011). Further publications have interjected nomenclatorial revisions without accompanying fieldwork (Blind, 1963; Hengsbach,

\footnotetext{
${ }^{1}$ Maurenstraße 26, 78194 Immendingen-Hattingen, Germany; Armin.Scherzinger@t-online.de.

${ }^{2}$ Landhausstraße 20, 72411 Bodelshausen, Germany; g.g.landhaus@t-online.de.

${ }^{3}$ Staatliches Museum für Naturkunde, Rosenstein 1, 70191 Stuttgart, Germany; guenter.schweigert@smns-bw.de.
} 


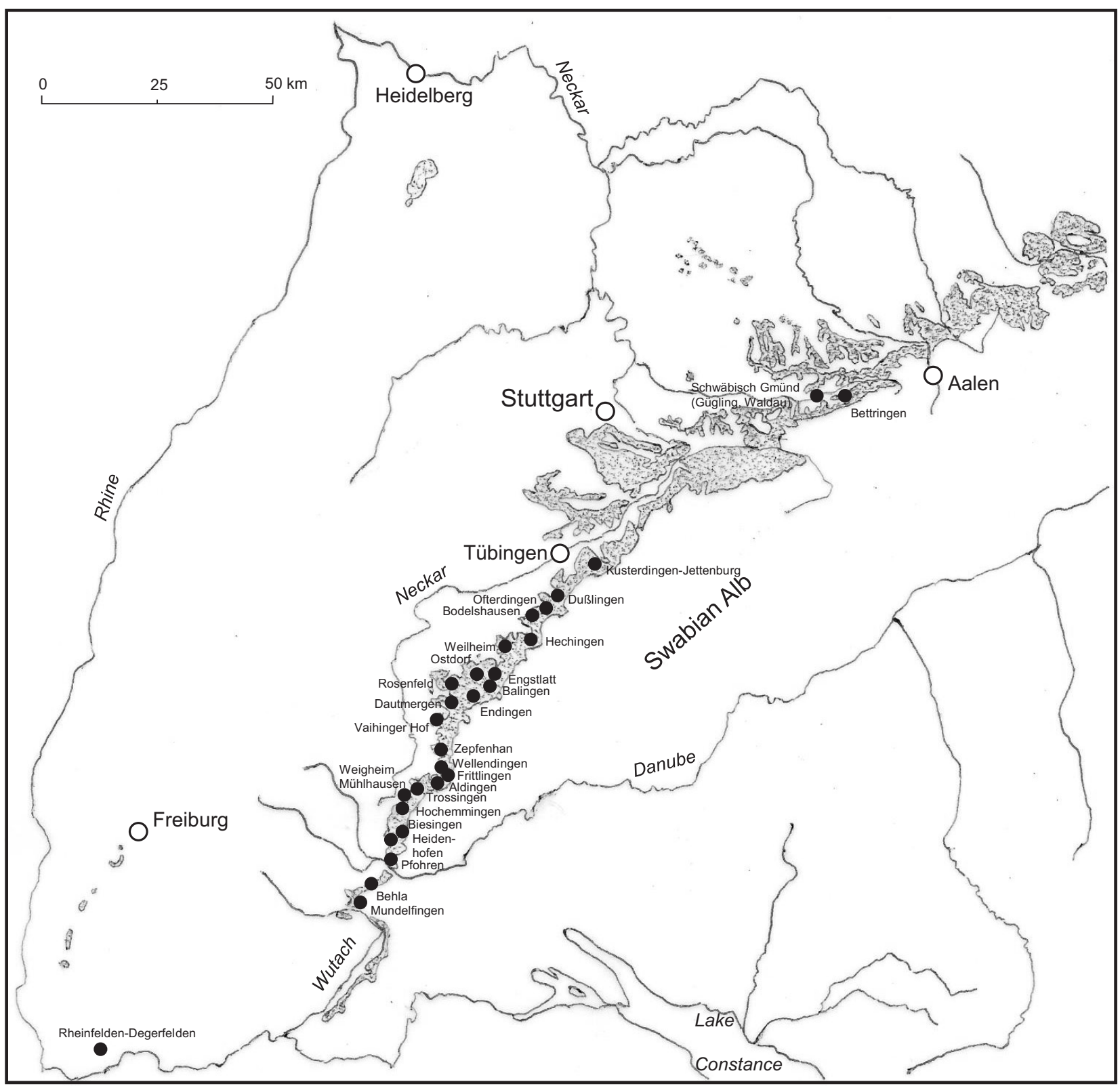

Fig. 1. Studied localities in the Lower Jurassic of SW Germany

1986a, b) or have provided palaeoenvironmental interpretations without exact biostratigraphical data (Grüner, 1997). If we compare the biostratigraphical data of Swabia with those of the same time interval in France (Corna, 1985, 1987; Corna et al., 1997) or in England (Page, 2003, 2010), the state of the art is rather unsatisfactory. Step-by-step we try here to establish a higher biostratigraphical resolution of the Arietenkalk Formation based on ammonite biohorizons. In addition, the natural systematic relationships of the Sinemurian ammonite genera Coroniceras, Arietites and Paracoroniceras can be cleared up only when considering their dimor- phism (at present microconchs of these genera are included in Arnioceras s.1.).

\section{MATERIAL AND METHODS}

Several sections of temporarily exposed outcrops and natural outcrops along streams were measured and ammonites were collected bed-by-bed, even taking account their position within a bed (Fig. 2). This is important since some beds are diagenetically merged in some sections, whereas 
$\frac{\pi}{\frac{0}{0}}$

$\frac{c}{d}$
$\frac{1}{0}$
$\frac{1}{2}$

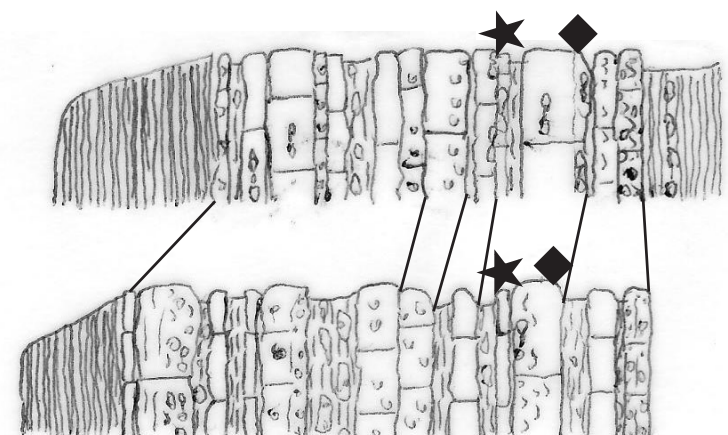

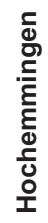

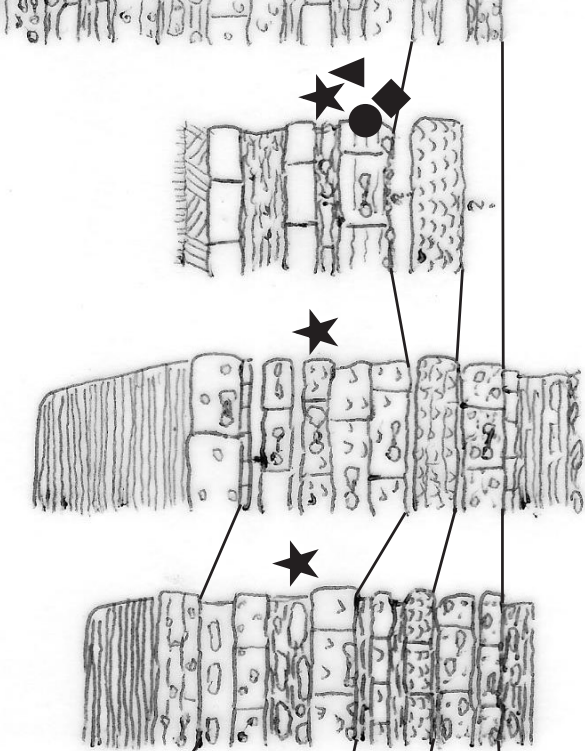

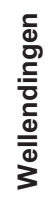

$\frac{N}{2}$

등

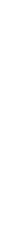

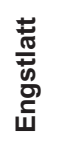

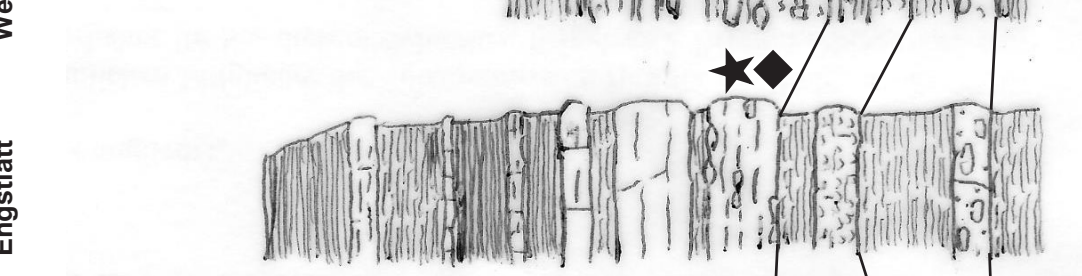

홍
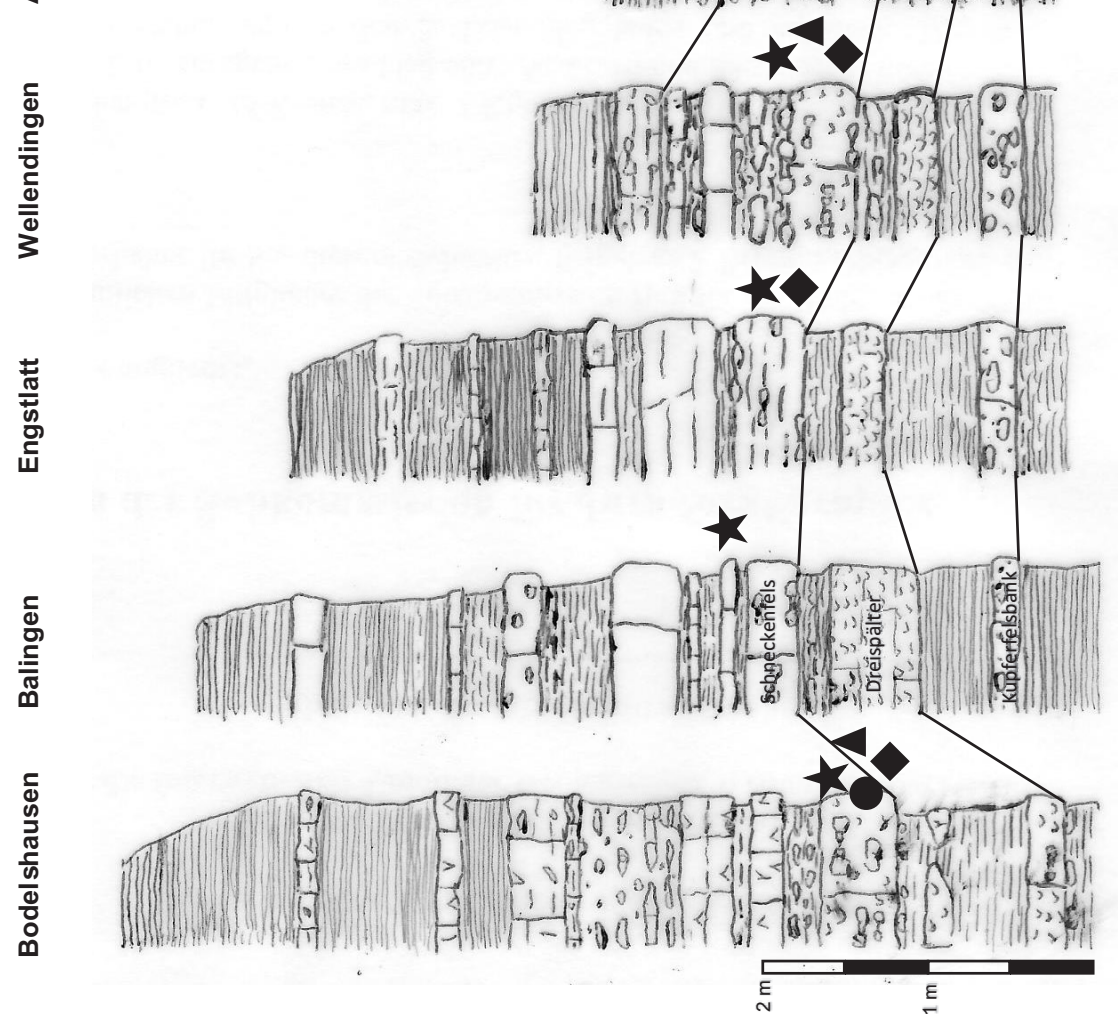

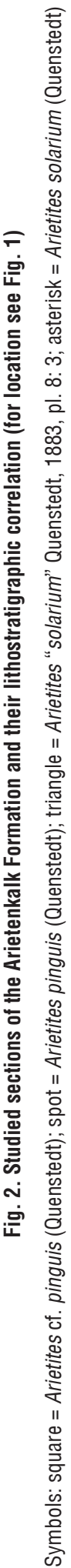


they are developed as individual beds in others. This makes previous lithological correlations lacking this biostratigraphical control somewhat unreliable (e.g., Vollrath, 1924; Frank, 1930; Walliser, 1956b). Gaps in the sedimentological record as well as reworking and condensation have to be considered. Apart from lithological correlations, in addition the taphonomy of the fossil content was documented. By means of the lithology of type specimens described from the study area we try to identify their type horizons. In addition to the newly collected material we have studied specimens in various public and private collections.

The illustrated material is stored in the palaeontological collections of Tübingen University (GPIT) and in the collection of the Staatliches Museum für Naturkunde Stuttgart (SMNS). A few additional specimens studied for comparison come from the private collections of Edmunt Bernt (Weissach-Flacht), Stefan Gräbenstein (Bodelshausen), Magdalene and Manfred Piperek (Albstadt-Ebingen), and Patrick Reger (Tuttlingen).

Abbreviations: $[\mathrm{m}]=$ microconch; $[\mathrm{M}]=$ macroconch .

\section{THE LOWER SINEMURIAN BUCKLANDI SUBZONE IN SOUTHWESTERN GERMANY}

The Arietenkalk Formation consists of an up to 22 metres (in most sections between 2.5-6.0 metres) thick set of biodetritic limestones with intercalated marly layers and occasional bituminous shales in its upper part. It overlies the Angulatensandstein or Angulatenton formations and is followed by the predominantly clayey Obtususton Formation. The lower part of the Arietenkalk Formation is Early Sinemurian in age; its higher parts are already Late Sinemurian in age (Schlatter, 1976; Bloos, 1984; Bloos et al., 2005). Lithologically, the lower boundary of the Arietenkalk Formation is drawn with the base of the Kupferfelsbank, an ironoolithic limestone bed of the Conybeari and Rotiforme subzones of the Bucklandi Zone. Here we focus on the third subzone of the Bucklandi Zone, the Bucklandi Subzone.

In the area of the Baar and in the adjacent foreland of the western Swabian Alb there is an easily recognizable thick limestone bed in the lower, but not lowermost Arietenkalk Formation. This bed often splits into three thinner beds, which is why it was called "Dreispälter" by the local quarrymen (e.g., Wilhelm, 1926; Walliser, 1956b). In some localities (Aldingen 1, Trossingen) the base of this bed yields coarsely ribbed Arnioceras sp. and Coroniceras ex gr. caprotinum (d'Orbigny, 1844) / Coroniceras planicosta Blind, 1963. Locally in the lower part of this bed also Coroniceras ex gr. hyatti Donovan, 1952 (Rosenfeld, Balingen, Balingen-Engstlatt, and Rheinfelden-Degerfelden in the Dinkelberg area) and Coroniceras coronaries (Quenstedt, 1883) (Trossingen) exist. Above follows a very distinct ammonite fauna, in which Vermiceras scylla (Reynès, 1879) predominates by far, accompanied by rare Angulaticeras ventricosum (Sowerby, 1816) and the exotic Tethyan Canavarites meisteri Schweigert, Kapitzke et Schreiber, 2011. After Corna (1985), Page (2003, 2010) and Schweigert et al. (2011), this scylla Biohorizon is characteristic for the basal Bucklandi Subzone. Hence, the boundary between the Rotiforme and Bucklandi subzones must be located within the "Dreispälter" limestone bed.

The top of the Bucklandi Subzone is better traceable in the southern Baar area (Pfohren, Behla) than in the foreland of the western Swabian Alb. There, above a well-developed "Schneckenfels" bed with abundant Arietites cf. pinguis (Quenstedt, 1883) at the base and a thinner limestone bed with Arietites solarium (Quenstedt, 1883) follows a prominent marlstone bed with some fragmentary Paracoroniceras ex gr. lyra Hyatt. Then follows a $c a .20 \mathrm{~cm}$ thick, light gray limestone with Paracoroniceras ex gr. charlesi Donovan. This bed and the underlying marlstone belong to the Semicostatum Zone. At Behla, we recovered a few incomplete specimens of Paracoroniceras ex gr. lyra from the base of this bed, but unfortunately, there is no record of Paracoroniceras ex gr. charlesi in the top. Further sampling in the study area allowed us to distinguish six ammonite biohorizons within the Bucklandi Subzone (see Table 1). Compared with published data from the Bucklandi Subzone of France and England (Corna, 1985; Page, 2003, 2010) it appears that in these areas the sections are more complete at the base (scylla Biohorizon) and in the top (three biohorizons) of this Subzone. The biohorizons of the middle part of the Bucklandi Zone, which are recorded in SW Germany, are missing in French and English references. Whether this non-record points to a gap in the rock record or results from collecting biases cannot be cleared up without further studies in England and France. In this context it seems important to define the exact horizon of the zonal index Arietites bucklandi (Sowerby, 1816), the neotype of which comes from Keynsham in Somerset (Donovan, 1952). Donovan (1952) and Dean et al. (1961) figured two further specimens of "Arietites bucklandi" from the Manor Road Quarry at Keynsham. In our opinion, the latter specimens do not represent Arietites bucklandi (Sowerby, 1816), since both lack the striking strongly curved ribbing style of the neotype. Unfortunately, the two specimens are too incomplete for a more precise determination. In consequence, the English material needs a fundamental revision, also to get an idea about the taxonomic status of Arietites scunthorpense (Spath, $1924=\mathrm{Am}$ monites bucklandi in Wright, 1878, pl. 1: 1, holotype) and of Arietites quadratum Donovan, 1952. Guérin-Franiatte (1966, pl. 2) figured a specimen of a typical Arietites buck- 
Preliminary results about the succession of ammonite biohorizons in the Lower Sinemurian of SW Germany

\begin{tabular}{|c|c|c|c|}
\hline Zone & Subzone & Horizon & Locality \\
\hline \multirow{6}{*}{ 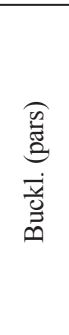 } & \multirow{6}{*}{ 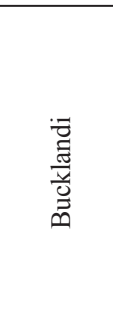 } & solarium & $\begin{array}{l}\text { Behla, Pfohren, Hochemmingen, Mühlhausen, Aldingen, Frittlingen, Wellendingen, Vaihingerhof, } \\
\text { Endingen, Engstlatt, Balingen, Bodelshausen, Ofterdingen }\end{array}$ \\
\hline & & cf. solarium & Hochemmingen, Trossingen, Ostdorf, Engstlatt \\
\hline & & "solarium" & Trossingen, Wellendingen, Endingen, Hechingen \\
\hline & & pinguis & Hochemmingen, Mühlhausen, Trossingen, Wellendingen, Bodelshausen \\
\hline & & cf. pinguis & $\begin{array}{l}\text { Degerfelden, Behla, Pfohren, Hochemmingen, Mühlhausen, Weigheim, Trossingen, Aldingen, } \\
\text { Frittlingen, Wellendingen, Endingen, Engstlatt, Balingen, Hechingen, Bodelshausen, Ofterdingen }\end{array}$ \\
\hline & & scylla & $\begin{array}{l}\text { Pfohren, Biesingen/Baar, Heidenhofen, Hochemmingen, Mühlhausen, Weigheim, Trossingen, } \\
\text { Aldingen, Frittlingen, Wellendingen, Zepfenhan, Dautmergen, Endingen, Balingen, Weilheim }\end{array}$ \\
\hline
\end{tabular}

landi (Sowerby, 1816) from St.-André-en-Terre-Plaine (Yonne, France).

In our opinion, A. bucklandi must be expected in beds not earlier than near the top of the middle part of the Bucklandi Subzone according to the phyletic trends of the genus Arietites (for more details see below). Considering the entire phyletic lineage of the genus, the type horizon of Arietites bucklandi is most likely only a little bit older than that of Arietites solarium (Quenstedt). We here focus on the bed containing Arietites solarium.

\section{TAXONOMIC HISTORY OF ARIETITES SOLARIUM}

Quenstedt (1883: 59) explained that the local quarrymen in the area between Balingen and Hechingen named the special limestone bed containing Ammonites solarium the "Uhrenfels" (= "rock with clocks"), after the shape of these ammonites resembling giant dials. This gives us a relatively precise hint where to look for the type horizon of this species. However, Quenstedt (1883, p. 63) stated that there exist transitional forms between his new taxon solarium (pl. 8: 1) and the long-known Ammonites bucklandi Sowerby, 1816 even at the same locality. Moreover, he obviously took the "Uhrenfels" and the "Schneckenpflaster", both limestone beds with giant arietitids, at least partly as synonymous (Quenstedt, 1883, p. 41).

Some authors (Schmidt, 1914; Donovan, 1952; Arkell, 1956; Guérin-Franiatte, 1966; Schlegelmilch, 1976) accepted Arietites solarium as a valid species, whereas others (Joly, 1936) interpreted Arietites solarium as a junior subjective synonym of Arietites bucklandi. For a solid definition of the taxon Ammonites solarium we have to go back to the original description by Quenstedt (1883).

When Quenstedt introduced the name for his new taxon, he mentioned or described eight specimens, all of them coming from the foreland of the western Swabian Alb and adjacent Baar:
1. A very big specimen with a diameter of about $60 \mathrm{~cm}$ and 21 [22] ribs on the outer whorl; from the area between Hechingen and Balingen, exact locality not mentioned, unfigured.

2. A specimen with a diameter of $49 \mathrm{~cm}$ and 21 ribs on the last whorl, from Balingen-Endingen (Quenstedt, 1883, pl. 8: 1).

3. A specimen from Trossingen, with a diameter of $40 \mathrm{~cm}$ and 24 ribs on the last whorl (Quenstedt, 1883, pl. 8: 2).

4. A specimen from the "Schneckenpflaster" of the Steinlach river at Dußlingen near Tübingen, with a diameter of $48 \mathrm{~cm}$ and 24 ribs on the last whorl (Quenstedt, 1883, pl. 8: 3).

5. A specimen from Balingen-Endingen, diameter $55 \mathrm{~cm}$, 26 ribs on the last whorl, unfigured.

6. A specimen from Balingen-Endingen, diameter $49 \mathrm{~cm}$, 27 ribs on the last whorl, unfigured.

7. A specimen from Kusterdingen-Jettenburg near Tübingen, diameter $58 \mathrm{~cm}, 31$ ribs on the last whorl, unfigured.

8. A specimen from Schwäbisch Gmünd, diameter $63 \mathrm{~cm}$, 30 ribs on the last whorl, unfigured.

Following Quenstedt himself, of his three figured specimens only the first one (specimen 2, see above) is a typical solarium, whereas the two others were said to be somewhat transitional to Arietites bucklandi. Subsequently, Donovan (1952, p. 720) designated specimen (2) as the lectotype of Arietites solarium, followed by Guérin-Franiatte (1966). Both authors mentioned that the specimens illustrated on plate 8: 2, 3 were missing. However, since Guérin-Franiatte $(1966: 110,111)$ had measured a diameter of $58.5 \mathrm{~cm}$ for the presumed lectotype; this specimen was most likely misidentified, because this diameter is not at all the diameter given for Quenstedt's figure 1, but it fits with that of the unfigured specimen (1). Today, none of the figured specimens could be traced in the palaeontological collection of Tübingen University. The only specimen that had survived in the collection until now is the previously unfigured specimen (1). It was identified by the remains of a labelling with ink 
indicating that it is a Quenstedt original and the only one that fits quite well with Quenstedt's description. Since it is not sure whether Donovan (1952) had really studied the specimen he declared as the lectotype, we here designate the sole surviving specimen of Quenstedt's type series as the neotype of Ammonites solarium.

\section{THE HORIZON OF ARIETITES SOLARIUM IN THE ARIETENKALK FORMATION}

In all of our studied sections, Arietites solarium follows above the occurrence of Arietites ex gr. bucklandi and closely related forms, which are in need of a revision (Table 1). The ammonite fauna of the solarium horizon yields only the following taxa: Arietites solarium (Quenstedt) [M], Arnioceras $\mathrm{sp} .[\mathrm{m}]$.

In some of the studied sections the solarium Biohorizon is recorded in a limestone bed either completely merged with the underlying "Schneckenfels" bed or separated from the latter by a thin marly layer only (e.g., sections Mühlhausen, Aldingen 1, Bodelshausen, Engstlatt in Gebhard, Schlatter 1977, fig. 1). Locally, this bed forms a knotty limestone within a marlstone bed with abundant Gryphaea arcuata Lamarck, 1801 (Wellendingen, Behla). This situation corresponds with Quenstedt's description of limestone concretions within marly beds just above the "Schneckenfels" bed yielding giant ammonites. However, locally the lithology of the bed containing Arietites solarium can change over a distance of only 20 to 30 metres. It is either represented by a well-developed limestone bed with a thickness of 20 to $25 \mathrm{~cm}$ (e.g., Mühlhausen, Hochemmingen, Wellendingen, Aldingen 1), by a thin knobby limestone layer (e.g., Wellendingen, Aldingen 2, Behla, Pfohren), or represented by occasional limestone nodules only (e.g., Behla). Walliser (1956a, b) did not mention Arietites solarium from any of his studied sections. A reason could be that Fiege (1929) had interpreted Arietites solarium as a synonym of Arietites pinguis (Quenstedt, 1883) and indeed the specimen of Quenstedt's pl. 8: 2 from Trossingen could belong to the latter species or is closely related. In the Wutach area, a fragmentary specimen was recorded as Arietites solarium by v. Reis (1981) from the Arietenkalk section of the Mundelfingen waterfall, however, lacking exact data about its position within that section. In our opinion, this specimen represents a stratigraphically earlier species of this genus because of its dense, regular ribbing style.

Riek (1966) studied the Arietenkalk Formation in the foreland of the middle Swabian Alb including the Filder area south of Stuttgart. Hitherto, there are indeed no records of A. solarium from that area, either due to collection biases or - more likely - to a hiatus in the stratigraphical record. In eastern Swabia (e.g., Gügling, Waldau, Bettringen near Schwäbisch Gmünd; Coll. E. Bernt, Weissach-Flacht and Coll. H. Schöne, GPIT) only forerunners of $A$. solarium have been recorded yet.

In the foreland of the western Swabian Alb (e.g., Wellendingen) the horizon with Arietites solarium is often followed by a knotty limestone bed which contains usually badly preserved Paracoroniceras sp. In other localities (e.g., Aldingen, Trossingen, Balingen-Engstlatt) it seems this bed is developed as a thicker limestone bed with giant Paracoroniceras ex gr. charlesi. This gives us a hint that at least the latter bed or the marlstone just below belongs to the Semicostatum Zone. In the section Aldingen 2 the "Schneckenfels" bed is followed by three well-developed limestone beds of the Bucklandi Zone and probably of the Semicostatum Zone (Fig. 2). The transition between the Bucklandi and Semicostatum zones is diversely developed in the study area showing rapid lateral lithological changes.

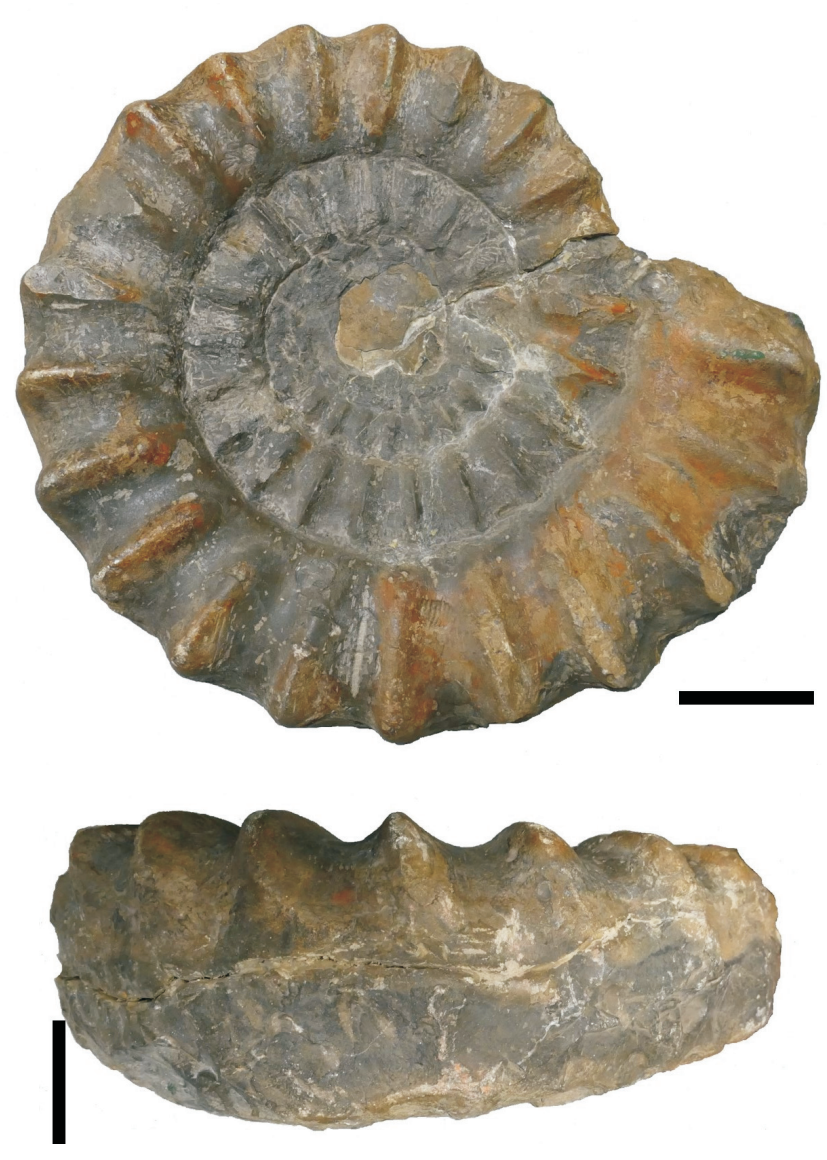

Fig. 3. Arietites solarium (Quenstedt)

Specimen GPIT/CP/10346, neotype, in ventral (A) and lateral views (B), SW Germany; Arietenkalk Formation, Lower Sinemurian, Bucklandi Zone, Bucklandi Subzone, solarium Biohorizon. Scale bar $=10 \mathrm{~cm}$ 


\section{SYSTEMATIC PALAEONTOLOGY}

Family Arietitidae Hyatt, 1874

Subfamily Arietitinae Hyatt, 1874

Genus Arietites Waagen, 1869

Arietites solarium (Quenstedt, 1883)

pars 1883. Ammonites solarium - Quenstedt, p. 59, pl. 8: 1 (cf.), non figs. $2,3$.

1914. Arietites solarium Quenstedt - Schmidt, p. 9, pl. 1: 1. pars 1936. Ammonites solarius F. Quenstedt - Joly, p. 52. pars 1952. Arietites solarium (Quenstedt) - Donovan, p. 719. 1956. Arietites solarium (Qu.) - Arkell, p. 130.

1966. Arietites solarium (Quenstedt, 1883) - Guérin-Franiatte, p. 110, pl. 4; text-figs. 20, 21.

non 1976. Arietites solarium (Qu.) - Schlegelmilch, p. 138, pl. 14: 3 (forerunner of $A$. solarium).

non 1981. Arietites (Arietites) solarium (Quenstedt) - v. Reis, pl. 2: 1.
Neotype. Designated herein, the specimen mentioned by Quenstedt (1883: 59), GPIT/CP/10346, illustrated for the first time on Figure 3.

Type locality. Foreland of the western Swabian Alb in the area between the towns of Hechingen and Balingen, Baden-Wuerttemberg, southern Germany. Exact locality unknown.

Type horizon. Lower part of Arietenkalk Formation, a limestone bed directly overlying the "Schneckenfels" bed (Bucklandi Zone, Bucklandi Subzone, solarium Horizon).

Description. Arietites solarium (Figs. 3-5) is a large- to giant-sized species of the genus characterized by a relatively involute coiling and an extremely wide-spaced constant radiate ribbing ( $c a$. 21-23 per whorl) in the preadult and adult stages; only inner whorls denser ribbed. Whorl section subquadratic.

Occurrences. Within the Early Sinemurian Bucklandi Zone/Bucklandi Subzone, Arietites solarium seems to be restricted to a thin limestone bed biostratigraphically representing the solarium Biohorizon. In southwestern Germany, A. solarium is frequently recorded from the Baar area and the adjacent foreland of the western Swabian Alb (Behla, Pfohren, Hochemmingen, Mühlhausen near Schwenningen,

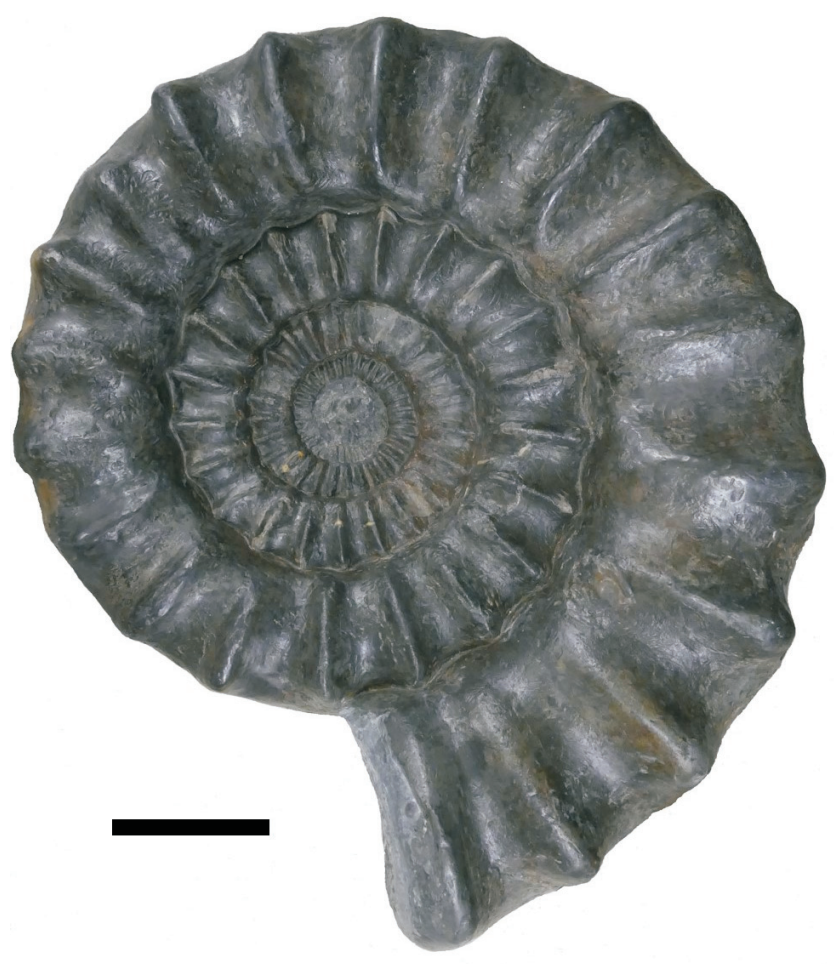

Fig. 4. Arietites solarium (Quenstedt)

Specimen SMNS 60956, Balingen-Endingen, SW Germany; Arietenkalk Formation, Lower Sinemurian, Bucklandi Zone, Bucklandi Subzone, solarium Biohorizon. Scale bar $=10 \mathrm{~cm}$

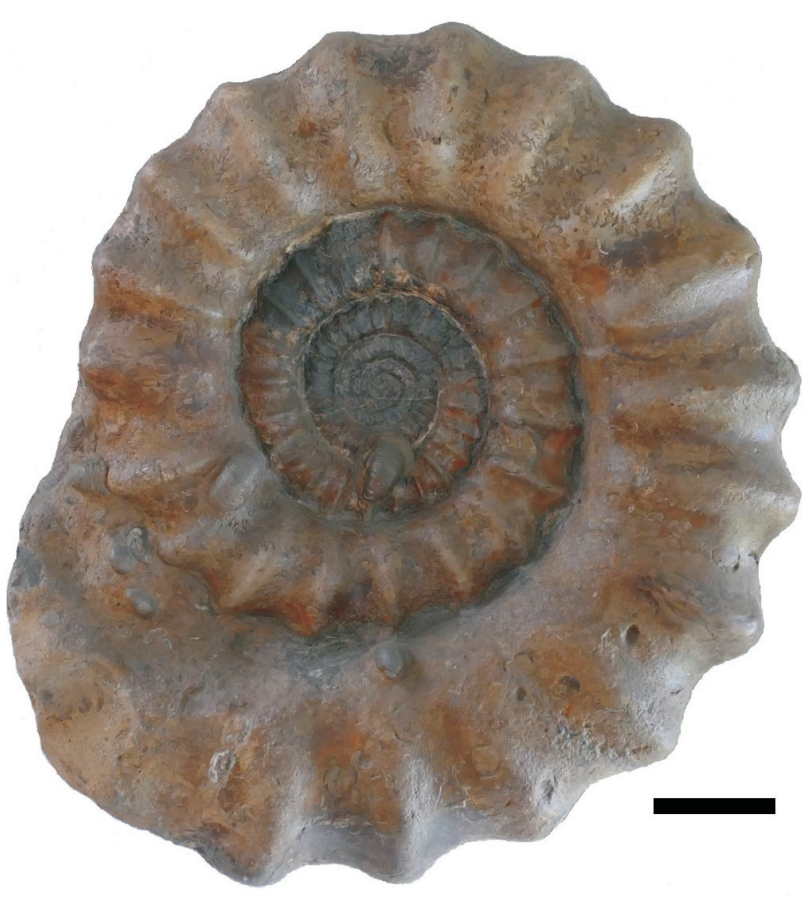

Fig. 5. Arietites solarium (Quenstedt)

Specimen SMNS 70526, Hochemmingen, SW Germany; Arietenkalk Formation, Lower Sinemurian, Bucklandi Zone, Bucklandi Subzone, solarium Biohorizon. Scale bar $=10 \mathrm{~cm}$ 
Aldingen, Frittlingen, Wellendingen, Vaihinger Hof, Balingen-Endingen, Balingen-Engstlatt, Bodelshausen, Ofterdingen). Besides southern Germany, Arietites solarium occurs in northern Germany (Bad Harzburg: Schmidt, 1914) and in France (Troutry, Cote d'Or: Guérin-Franiatte, 1966). Most likely, there exist further records from several other French localities (Guérin-Franiatte, 1966), but none of them has yet been illustrated. Moreover, Donovan $(1952,1956)$ mentioned a sole specimen from the Saltford railroad cutting near Bath which he identified as Arietites solarium; however, the latter specimen was not illustrated either.

\section{DISCUSSION AND CONCLUSIONS}

Early species of Arietites (A. pinguis and forerunners) and transitional forms between $A$. bucklandi and A. solarium are restricted to the "Schneckenfels" bed and do not occur higher up in the section. Quenstedt's specimen illustrated on his pl. 8: 2 corresponds to early representatives of Arietites ex gr. bucklandi, a form that we have recorded frequently from the basal part of the "Schneckenfels" bed at numerous localities (e.g., Hochemmingen, Trossingen, Pfohren, Wellendingen) here classified as Arietites cf. pinguis [M]. It is accompanied by Arietites costosum (Quenstedt, 1883) [M], Arnioceras subgeometricum Jaworski, 1931 [m], Eucoroniceras sp. $[\mathrm{M}+\mathrm{m}]$, and Tmaegoceras crassiceps Pompeckj, 1901 [m]. The same fauna is recorded also from Rheinfelden-Degenfelden (Hagenbacher Hof, Dinkelberg).

Quenstedt's specimen of his pl. 8: 3 differs from that of pl. 8: 2 by its thicker and wider spaced ribs; this morphology occurs in the middle part of the "Schneckenfels" bed (e.g., Hochemmingen, Wellendingen, Balingen-Endingen, Hechingen). This form is very close to the neotype of Arietites bucklandi from Keynsham, Avon, England (The Natural History Museum, BMNH C.41796) (see e.g., Arkell, 1956; Guérin-Franiatte, 1966; Howarth, 2013), but the inner whorls exhibit straight, wide-spaced ribs, in contrast to true A. bucklandi, in which strongly curved ribs appear already in the inner whorls.

In the higher part of the "Schneckenfels" bed occur specimens of Arietites ex gr. bucklandi with a thick, rounded whorl section and thick, wider spaced ribs in the final stage. Like in Arietites solarium, the ribs are slightly prorsiradiate, but they still lack the stage with typically raised ventral ribs already at low diameters, and the inner whorls exhibit a significantly denser ribbing. This form can be interpreted as a phyletic forerunner of Arietites solarium.

This adds to the biostratigraphical frame of biohorizons under study by the authors (Table 1). The type horizon of A. solarium is located above beds with Arietites ex gr. pin- guis and Arietites ex gr. bucklandi. Since, as discussed above, these taxa are linked by transitional forms from various layers of the "Schneckenfels" bed, they can be interpreted as members of a phyletic lineage, with $A$. solarium as the terminal form:

1. A. cf. pinguis (Quenstedt, 1883): More evolute coiling, dense, straight ribs in the inner whorls, curved ribs on the outer whorl; big specimens with higher whorl section and wide-spaced coarse, curved ribs. Distribution: base of the "Schneckenfels" bed (Hochemmingen, Mühlhausen near Schwenningen, Trossingen, Bodelshausen, Ofterdingen).

2. A. pinguis (Quenstedt, 1883): More evolute coiling, dense, straight ribs in the inner whorls; stage of straight ribs changes earlier in the curved ribbing stage than in the previous form, this curved stage begins in the second last whorl, where the ribbing is coarser than in the forerunners. Coiling is a little more involute in the last two whorls. Distribution: lower part of the "Schneckenfels" bed, above the level of $A$. cf. pinguis (Mühlhausen near Schwenningen, Hochemmingen, Wellendingen).

3. A. "solarium" sensu Quenstedt, 1883, pl. 8: 3: Innermost whorls with dense, straight ribbing; the coarse, but still straight ribbing stage starts in the third last whorl with coarse curved ribs in the outer whorls. Distribution: higher part of the "Schneckenfels" bed, above the level of A. pinguis (Wellendingen, Trossingen, Balingen-Endingen, Hechingen).

4. A. cf. solarium: A large- to giant-sized species of the genus characterized by a relatively involute coiling, dense ribbing in the juvenile stage only and an extremely widespaced constant ribbing ( $c a$. 21-23 per whorl) in the preadult and adult stages. Prominent, slightly curved shovel-like ribs in the adult stage (straight ribs in true A. solarium). Whorl section subquadratic in the adult stage, more rounded in the inner whorls. Distribution: higher part of the "Schneckenfels" bed, above the level of A. "solarium" sensu Quenstedt, 1883, pl. 8: 3 and immediately below the level of $A$. solarium (Hochemmingen, Trossingen, Balingen-Ostdorf, Balingen-Engstlatt).

5. A. solarium (Quenstedt, 1883, neotype designated herein). Description and distribution see above.

Acknowledgements. We are grateful for information on unpublished sections and for numerous discussions and ammonite photographs, namely to Dr. Matthias Franz and Carolin Tetzel (both Landesamt für Geologie, Rohstoffe und Bergbau im Regierungspräsidium Freiburg im Breisgau), Dr. Christian Meister (Geneve), Norbert Wannenmacher (Bisingen-Thanheim), Elmar Scherer (Mössingen-Talheim), Magdalene and Manfred Piperek (Albstadt-Ebingen), Inge 
Bernt (Weissach-Flacht), Patrick Reger (Tuttlingen), Michael Kutz (Mackenheim), Klaus Jenne (Bötzingen), Wolfgang Auer (Altlussheim), Bernd Frohs (Bad Dürrheim), Till Kohler (Villingen-Schwenningen), Roland Berka (Singen), Murray Edmonds (Witney, Oxfordshire), and Martin Kapitzke (SMNS). Dr. Ingmar Werneburg (Tübingen) provided access to the palaeontological collection of Tübingen University. Paweł Zawada (Warszawa), Prof. Dr. Andrzej Wierzbowski (Warszawa) and Dr. John Wright (London) is thanked for formal and linguistic improvements. Dr. Joachim Blau (Frankfurt) and Dr. Christian Meister (Genève) provided helpful reviews for significant improvements of this paper.

\section{REFERENCES}

ARKELL W.J., 1956 - Jurassic Geology of the World. Oliver \& Boyd, Edinburgh \& London.

BLIND W., 1963 - Die Ammoniten des Lias alpha aus Schwaben, vom Fonsjoch und Breitenberg (Alpen) und ihre Entwicklung. Palaeontographica, A, 121: 38-131.

BLOOS G., 1979 - Über Ammonites ventricosus Sow. und ähnliche Schlotheimiiden im tieferen Sinemurium (Unterer Lias). Paläontologische Zeitschrift, 53: 142-162.

BLOOS G., 1984 - Les couches basales du Sinémurien, une révision stratigraphique. Cahiers de l'Institut Catholique de Lyon, 14: 59-68.

BLOOS G., 1988 - On the stage boundary Hettangian/Sinemurian in North-West Europe and in the North-Eastern Alps. $2^{\text {nd }}$ International Symposium on Jurassic Stratigraphy: 71-83, Lisboa.

BLOOS G., 2014 - On Ammonites silvestrei Reynès - a significant element of the Arietitinae in the Lower Jurassic (Lower Sinemurian, Bucklandi Zone, Rotiforme Subzone) of the NW European Province. Neues Jahrbuch für Geologie und Paläontologie, Abhandlungen, 274: 255-270.

BLOOS G., DIETL G., SCHWEIGERT G., 2005 - Der Jura Süddeutschlands in der Stratigraphischen Tabelle von Deutschland 2002. Newsletters on Stratigraphy, 41: 263-277.

BUCH L., von, 1839 - Über den Jura in Deutschland. Königliche Akademie der Wissenschaften, Berlin.

CORNA M., 1985 - Le Lias de Jura meridional. Paléontologie biostratigraphique du Sinémurien. Approche paléoécologique. Thèse 3e cycle Universite Lyon.

CORNA M., 1987 - Les horizons sinémurien du Calcaires à gryphées du Jura méridional français (zone à Conybeari - zone à Obtusum). Géobios, 20: 531-536.

CORNA M., DOMMERGUES J.-L., MEISTER C., MOUTERDE R., 1997 - 2. Sinemurien: 106-113. In: Biostratigraphie du Jurassique ouest-européen et méditerranéen: zonations parallèles et distribution des invertébrés et microfossiles (coord. É. Cariou, P. Hantzpergue). Bulletin du Centre de Recherches Elf Exploration et Production, Mémoire, 17: 1-440.

DEAN W.T., DONOVAN D.T., HOWARTH M.K., 1961 - The Liassic ammonite zones and subzones of the north-west European Province. Bulletin of the British Museum (Natural History), Geology Series, 4: 435-505.
DIETZ A., 1922 - Untersuchungen über die Lobenlinie der Ammoniten des Lias $\alpha-\gamma$. Neues Jahrbuch für Mineralogie, Geologie und Paläontologie, Beilage-Band, 47: 381-494.

DONOVAN D.T., 1952 - The ammonites of the Blue Lias of the Bristol district. Part II. Arietitidae. The Annals and Magazine of Natural History, 12, 5: 717-752.

DONOVAN D.T., 1956 - The zonal stratigraphy of Blue Lias around Keynsham, Somerset. Proceedings of the Geologists' Association, 66: 182-212.

FIEGE K., 1926 - Ein biostratigraphischer Vergleich der Arietenschichten Württembergs und Norddeutschlands. Zeitschrift der Deutschen Geologischen Gesellschaft, 78: 20-212.

FIEGE K., 1929 - Die Biostratigraphie der Arietenschichten Nordwestdeutschlands und Württembergs. Palaeontographica, 71: 67-116.

FRANK M., 1930 - Beiträge zur Stratigraphie und Paläogeographie des Lias alpha in Süddeutschland. Mitteilungen der Geologischen Abteilung des Württembergischen Statistischen Landesamtes, 13, 4: 1-242.

GEBHARD G., SCHLATTER R., 1977 - Über das Vorkommen von Tmaegoceras Hyatt (Ammonoidea) im Lias Europas. Stuttgarter Beiträge zur Naturkunde, Serie B, 22: 1-15.

GRÜNER M., 1997 - Dynamische Paläoökologie und taxonomische Bearbeitung des Unterjura (Hettangium bis unteres Sinemurium) auf der Schwäbischen Alb. Profil, 11: 1-197.

GUÉRIN-FRANIATTE S., 1966 - Ammonites du Lias inférieur de France, Psilocerataceae, Arietitidae. Centre National de la Recherche Scientifique, Paris.

HENGSBACH R., 1986a - Über Arnioceras falcaries (Quenstedt) und einige verwandte Arten aus Mitteldeutschland (Ammonoidea; Lias). Senckenbergiana Lethaea, 67: 151-170.

HENGSBACH R., 1986b - Über Ammonites dorsosulcatus Quenstedt 1884. Senckenbergiana Lethaea, 67: 331-336.

HOFFMANN K., 1964 - Die Stufe des Lotharingien (Lotharingium) im Unterlias Deutschlands und allgemeine Betrachtungen über das „Lotharingien”. In: Colloque du Jurassique à Luxembourg, 1962: 135-160.

HÖLDER H., 1936 - Neue Schlotheimien aus den unteren Arietenschichten von Vaihingen auf den Fildern. Jahreshefte des Vereins für vaterländische Naturkunde in Württemberg, 92: $1-9$.

HOWARTH M.K., 2013 - Treatise Online, No. 57, Part L, Revised, Vol. 3B, Chapter 4: Psiloceratoidea, Eodoceratoidea, Hildoceratoidea. Paleontological Institute, The University of Kansas.

HYATT A., 1874 - Remarks on two new genera of ammonites, Agassiceras and Oxynoticeras. Proceedings of the Boston Society of Natural History, 17: 225-235.

HYATT A., 1889 - Genesis of the Arietidae. Smithsonian Contributions to Knowledge, 673: 1-238.

JAWORSKI E., 1931 - Über Arnioceras geometricum Oppel und verwandte Spezies; nebst einem Anhang über Ammonites natrix Schlotheim, 1820. Neues Jahrbuch für Mineralogie, Geologie und Paläontologie, 65: 83-140.

JOLY H., 1936 - Les fossiles du Jurassique de la Belgique. Avec description stratigraphique de chaque étage. Deuxième partie Lias inférieur. Mémoire du Musée Royal d'Histoire Naturelle de Belgique, 79: 1-244. 
LAMARCK J.B., 1801 - Systême des Animaux sans Vertèbres. Librairie Deterville, Paris.

OPPEL A., 1856 - Die Juraformation Englands, Frankreichs und des südwestlichen Deutschlands. Jahreshefte des Vereins für vaterländische Naturkunde in Württemberg, 12: 121-556.

OPPEL A., 1862 - Ueber jurassische Cephalopoden. Palaeontologische Mittheilungen aus dem Museum des koeniglich Bayerischen Staates, 1: 127-162.

d'ORBIGNY A., 1842-1849 - Paléontologie française: Terrains jurassiques. tome 1, Céphalopodes. Librairie Victor Masson, Paris.

PAGE K.N., 2003 - The Lower Jurassic of Europe: its subdivision and correlation. Geological Survey of Denmark and Greenland Bulletin, 1: 23-59.

PAGE K.N., 2010 - Stratigraphical framework. In: Fossils from the Lower Lias of the Dorset Coast (eds. A.R. Lord, P.G. Davies). The Palaeontological Association, London.

POMPECKJ J., 1893-1896 - Beiträge zu einer Revision der Ammoniten des Schwäbischen Jura. Schweizerbart'sche Verlagsbuchhandlung, Stuttgart.

POMPECKJ J., 1901 - Über Tmaegoceras Hyatt. Neues Jahrbuch für Mineralogie, Geologie und Paläontologie, 1901: 158-170.

QUENSTEDT F.A., 1845-1849 - Petrefactenkunde Deutschlands, 1. Abtheilung, Cephalopoden. Fues, Tübingen, 1-104, pls. 1-6 (1845); 105-184, pls. 7-12 (1846); 185-264, pls. 13-18 (1847); 265-472, pls. 19-30 (1848); 473-580, pls. 31-36 (1849).

QUENSTEDT F.A., 1856-1857 - Der Jura. Verlag der Laupp'schen Buchhandlung, Tübingen.

QUENSTEDT F.A., 1883-1885 - Die Ammoniten des Schwäbischen Jura. 1. Der Schwarze Jura (Lias). Schweizerbart'sche Verlagsbuchhandlung, Stuttgart.

REIS H., von, 1981 - Geologie der Schichtenfolge Mittlerer Keuper bis Unter-Malm im Gebiet „Achdorfer Wutachschlucht”, nördlich Achdorf, Schichtstufenland der Südwestbaar/Süddeutschland. Dipl.-Kartierung RWTH Aachen [unpublished].

REINECKE J.C.M., 1818 - Maris protogaei Nautilos et Argonautas vulgo Cornua Ammonis in agro Coburgico et vicino reperiundos. Ahl, Coburg.

REYNÈS P., 1879 - Monographie des Ammonites, 1re partie Lias. Baillière, Marseille \& Paris.

RIEK R., 1966 - Stratigraphie des Lias $\alpha 3$ (Arietenschichten) auf den Fildern. Jahreshefte des Vereins für vaterländische Naturkunde in Württemberg, 121: 169-190.

SCHLATTER R., 1976 - Die Stufe des Lotharingium im unteren Lias des Klettgau (Kanton Schaffhausen, Schweiz). Stuttgarter Beiträge zur Naturkunde, Serie B, 21: 1-21.

SCHLATTER R., 1983 - Über den Ammonites militaris MayerEymar 1865. Eclogae Geologicae Helvetiae, 76, 3: 701-717.
SCHLATTER R., 1984 - Zur systematischen Stellung der Gattung Epophioceras Spath (Ammonoidea). Jahresberichte und Mitteilungen des oberrheinischen geologischen Vereins, Neue Folge, 66: 175-185.

SCHLATTER R., 1988 - Wiederauffindung des Typusexemplars von Ammonites militaris Mayer-Eymar 1865. Mitteilungen der Naturforschenden Gesellschaft Schaffhausen, 33: 1-4.

SCHLEGELMILCH R., 1976 - Die Ammoniten des süddeutschen Lias. Gustav Fischer Verlag, Stuttgart.

SCHMIDT E.W., 1914 - Beiträge zur Paläontologie und Stratigraphie des nordwestdeutschen Jura. III. Die Arieten des unteren Lias von Harzburg. Palaeontographica, 61: 1-40.

SCHMIDT M., 1925 - Ammonitenstudien. Fortschritte in der Geologie und Palaeontologie, 10: 1-40.

SCHWEIGERT G., KAPITZKE M., SCHREIBER D., 2011 - First record of the Tethyan ammonite genus Canavarites Hyatt in the Lower Sinemurian of Germany, with description of a new species. Palaeodiversity, 4: 17-21.

SOWERBY J., 1815-1818 - The Mineral Conchology of Great Britain. Benjamin Meredith, London.

SPATH L.F., 1924 - The ammonites of the Blue Lias. Proceedings of the Geologists' Association, 35: 186-211.

STAHL C.F., 1824 - Uebersicht über die Versteinerungen Würtembergs nach dem gegenwärtigen Standpunkte der Petrefaktenkunde. Cotta'sche Buchhandlung, Stuttgart \& Tübingen.

VOLLRATH P., 1924 - Die Transgression des Jurameeres zwischen Schwäbischer Alb und Schweizer Jura. Centralblatt für Mineralogie, Geologie und Paläontologie, 1924: 18-26, 5359, 71-82.

WAAGEN W., 1869 - Die Formenreihe des Ammonites subradiatus. Geognostisch-Paläontologische Beiträge, 2: 181-257.

WALLISER O.H., 1956a - Chronologie des Lias a zwischen Fildern und Klettgau. Neues Jahrbuch für Geologie und Paläontologie, Abhandlungen, 103: 181-222.

WALLISER O.H., 1956b - Stratigraphie des Lias alpha zwischen Fildern und Klettgau (Arietenschichten, SW-Deutschland). Neues Jahrbuch für Geologie und Paläontologie, Abhandlungen, 103: 281-311.

WILHELM S., 1926 - Die Bodenbeschaffenheit unserer Baar und die Entstehung der Formen ihres Landschaftsbildes. In: Heimatblätter vom oberen Neckar (Ed. F.X. Singer), Oberndorf am Neckar.

WRIGHT T., 1878 - Monograph on the Lias ammonites of the British Islands. Palaeontographical Society Monographs, 32: $1-48$.

ZIETEN C.H., von, 1830-1833 - Die Versteinerungen Württembergs. Schweizerbart'sche Verlagsbuchhandlung, Stuttgart, IVIII + 1-16, pls. 1-12 (1830); 17-32, pls. 13-24 (1831); 3364, pls. 25-48 (1832); 65-102, pls. 49-72 (1833). 